\title{
KARAKTERSTIK SERAPAN SUARA KOMPOSIT POLYESTER BERPENGUAT SERAT TAPIS KELAPA
}

\author{
I Made Astika*, I Gusti Komang Dwijana \\ Jurusan Teknik Mesin Fakultas Teknik Universitas Udayana Kampus Bukit Jimbaran, Bali \\ Indonesia 80362. Phone/Fax: 0361703321 \\ *Email: imdastika@yahoo.com
}

\begin{abstract}
The purpose of this study is to investigate of sound absorption of coconut filter fiber composites. The research material made with coconut filter fiber as reinforcement and matrix resin unsaturated polyester (UPRs) type Yukalac BQTN 157 with 1\% hardener types MEKPO (Methyl Ethyl Ketone Peroxide) and fiber treatment by $0,5 \% \mathrm{KMnO}_{4}$. Production methods is poltrusion and the variations of fiber volume fraction are 20,25 and $30 \%$ and fiber length are 5 , 10 and $15 \mathrm{~mm}$. Testing of sound absorption frequency are 250, 500, 1000, 2000 and $4000 \mathrm{~Hz}$. The results of research show that the highest value of sound absorption coefficient is on the composites with composition of $10 \mathrm{~mm}$ fiber length and $30 \%$ fiber volume fraction, that is 0.550828 . The values are included in the class "Sound Absorption Coefficient Class D (Extremely absorbing)" with the range $0.40-0.60$ based on ISO standard 11654:1997.
\end{abstract}

Keywords : composites, coconut filter fiber, sound absorption

\section{PENDAHULUAN}

Perkembangan jaman yang semakin maju menyebabkan semakin berkembangnya peralatan yang digunakan oleh manusia seperti peralatan produksi, transportasi, komunikasi, sarana informasi dan hiburan. Sebagian besar peralatan tersebut menghasilkan suara-suara yang tidak diinginkan sehingga menimbulkan kebisingan. Untuk mengatasi hal tersebut dikembangkan berbagai jenis bahan peredam suara. Disamping itu peredam suara juga dibutuhkan untuk menciptakan bangunan atau gedung dengan karakteristik akustik tertentu sehingga tercipta kenyamanan bagi penggunanya.

Jenis bahan peredam suara yang sudah ada yaitu bahan berpori, resonator dan panel. Dari ketiga jenis bahan tersebut, bahan berporilah yang sering digunakan, khususnya untuk ruangan yang sempit seperti perumahan dan perkantoran. Hal ini disebabkan karena bahan berpori relatif lebih murah dan ringan dibandingkan dengan peredam lain (Youneung Lee, 2003). Material yang digunakan pada peredam suara jenis ini adalah glasswool dan rockwool. Karena harganya mahal, berbagai bahan pengganti material tersebut mulai dibuat. Diantaranya adalah berbagai macam gabus maupun bahan berkomposisi serat.

Kualitas dari bahan peredam suara ditunjukkan dengan harga a (koefisien penyerapan suara terhadap bunyi). Nilai $\alpha$ bernilai dari 0 sampai 1 . Semakin besar a maka semakin baik digunakan sebagai peredam suara. Jika $\alpha$ bernilai 0 berarti tidak ada bunyi yang diserap (dipantulkan).
Sedangkan bila a bernilai 1 , artinya semua (100\%) bunyi yang datang diserap oleh bahan (Farina, 2000) Pada tahun 2002 telah dikembangkan bahan peredam suara dari serat bambu yang mutunya bisa sebagus glasswool (Koizumi, 2003). Dan pada tahun 2003 telah dikembangkan peredam suara dari serat polyester daur ulang dan melakukan penelitian tentang penggunaan jerami untuk campuran bahan bangunan yang bisa meningkatkan penyerapan bunyi (Youneung Lee, 2003). Jika dilihat lebih mendalam, benda-benda disekeliling kita yang tampak kurang berguna ada yang bisa dimanfaatkan sebagai bahan peredam suara, salah satunya adalah serat tapis kelapa.

Dari permasalahan tersebut, dilakukan penelitian untuk mengetahui karakteristik redaman suara pada komposit polyester dengan penguat serat tapis kelapa. Komposit ini dapat diaplikasikan seperti pada komponen alat musik tradisional dan modern, maupun sebagai panel untuk interior ruangan ataupun asesoris kendaraan.

\section{TINJAUAN PUSTAKA \\ Komposit}

Komposit adalah suatu material yang terbentuk dari kombinasi dua atau lebih material, dimana sifat mekanik dari material pembentuknya berbeda-beda dimana satu material sebagai pengisi (Matrik) dan lainnya sebagai fasa penguat (Reinforcement). Komposit biasanya terdiri dari dua bahan dasar yaitu serat dan matrik. Serat biasanya bersifat elastis, mempunyai kekuatan tarik yang baik, namun tidak dapat digunakan pada 
temperatur yang tinggi sedangkan matrik biasanya bersifat ulet, lunak dan bersifat mengikat jika sudah mencapai titik bekunya. Kedua bahan yang mempunyai sifat berbeda ini digabungkan untuk mendapatkan satu bahan baru (komposit) yang mempunyai sifat yang berbeda dari sifat partikel penyusunnya (Gibson, 1994).

Suatu material komposit merupakan suatu material yang kompleks dimana terkomposisikan dari dua material atau lebih yang digabungkan/disatukan secara bersamaan pada skala makroskopik membentuk suatu produk yang berguna, yang didesain untuk menghasilkan kualitas maupun sifat terbaik. Penguat biasanya bersifat elastis, dan mempunyai kekuatan tarik yang baik namun tidak dapat digunakan pada temperatur yang tinggi, sedangkan matrik biasanya bersifat ulet, lunak dan bersifat mengikat jika sudah mencapai titik bekunya. Kedua bahan yang mempunyai sifat berbeda ini digabungkan untuk mendapatkan satu bahan baru (komposit) yang mempunyai sifat yang berbeda dari sifat partikel penyusunnya (Jacob, 2005).

Di dalam komposit dapat tebentuk interphase yaitu fase diantara fase matrik dan penguat yang dapat timbul akibat interaksi kimia antara kimia antara fase matrik dan fase penguat.

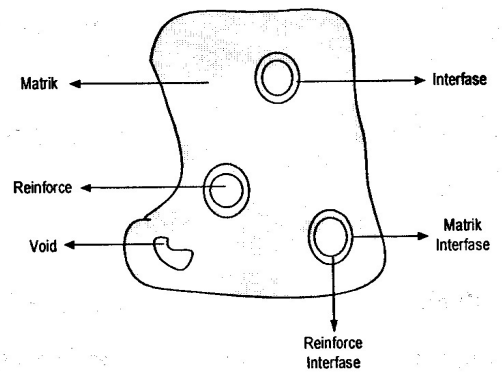

Gambar 1. Fase-fase dalam komposit, Jacob (2005)

Semakin berkembangnya teknologi memungkinkan komposit dapat didesain sedemikian rupa sesuai dengan karakteristik material yang diinginkan sehingga dapat dibuat menjadi lebih kuat, ringan dan kaku. Dengan beberapa kelebihan tersebut, menyebabkan komposit banyak diaplikasikan dalam peralatan-peralatan teknologi tinggi di bidang industri, transportasi dan konstruksi bangunan.

\section{Serat Tapis Kelapa}

Tapis Kelapa adalah serat yang terdapat pada pangkal tangkai daun pohon kelapa yang berfungsi menutupi pelepahnya.
Tanaman kelapa (Cocos nucifera L) banyak terdapat di daerah beriklim tropis. Pohon kelapa diperkirakan dapat ditemukan di lebih dari 80 negara. Indonesia merupakan negara agraris yang menempati posisi ketiga setelah filipina dan india, sebagai penghasil kelapa terbesar di dunia. Pohon ini merupakan tanaman yang sangat produktif, dimana dari daun hingga akarnya dapat diolah menjadi produk teknologi maupun untuk bangunan atau keperluan sehari-hari sehingga pohon kelapa dijuluki sebagai The Tree of Life (pohon kehidupan) dan $A$ Heavenly Tree (pohon surga) (Brahmakumar, 2005).

Tapis kelapa awalnya digunakan oleh masyarakat tradisional sebagai saringan kawat dan plastik yang memiliki kerapatan yang lebih merata tapis kelapa pun mulai ditinggalkan biasanya hanya digunakan untuk menyaring santan. Namun sekarang hanya menjadi limbah. Serat ini tersusun dari bahan yang menyerupai bahan pembentuk serabut kelapa. Walaupun jumlah yang dapat dihasilkan dalam satu pohon sangat terbatas namun tapis kelapa mempunyai keunggulan yaitu seratnya sudah tersusun dengan baik secara alami. Susunan serat dari tapis kelapa menyilang antara lapisan serat atas dengan lapisan serat bagian bawah. Karena keunggulan tersebut serat tapis kelapa cocok untuk dijadikan serat alternatif untuk pembuatan komposit.

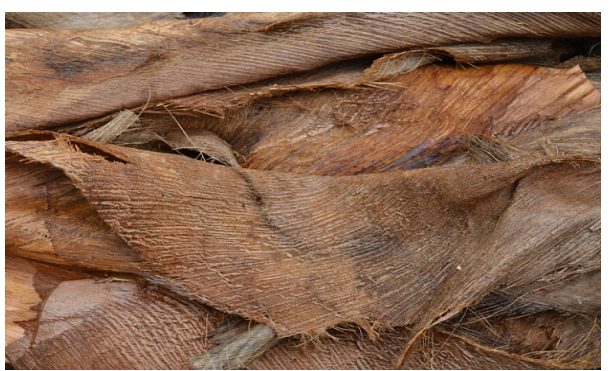

Gambar 2. Tapis kelapa

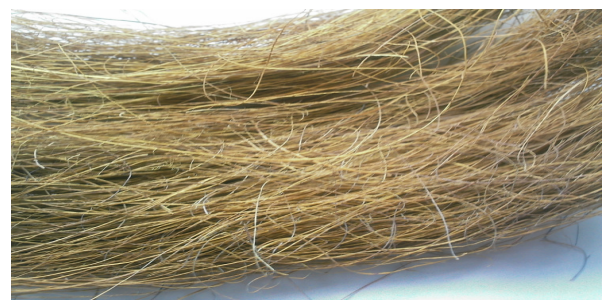

Gambar 3. Serat tapis kelapa

\section{Suara (Sound)}

Kata suara (sound) dapat terdefinisikan berdasarkan pandangan dari segi fisisnya 
adalah suatu penyimpangan tekanan (pressure), per-geseran partikel dalam suatu medium elastik yang mana dalam hal ini adalah udara (air). Bunyi merupakan sensasi pendengaran yang melewati telinga dan timbul karena penyimpangan tekanan udara (air pressure deviation). Penyimpangan ini biasanya disebabkan oleh beberapa benda yang bergetar, misalnya dawai gitar yang dipetik, atau garpu tala yang dipukul.

Pada kenyataannya suara merupakan suatu getaran, sehingga demikian berhubungan dengan getaran-getaran suara, yang ditimbulkan oleh apa yang dinamakan sebuah sumber suara, misalnya suara manusia, alat musik, radio dan sebagainya yang menghasilkan suara. Udara atau zat-zat lain yang berfungsi sebagai media getaran, meneruskan getaran-getaran ini dan semua ini sampai pada selaput gendang pendengaran manusia, dimana mereka menimbulkan sebuah suara.

Sewaktu udara atau zat lain melakukan getaran, bagian-bagian kecil tidak berpindah tempat, melainkan mereka bergerak ke sana ke mari mencari keseimbangan. Mereka bersentuhan dengan bagian-bagian yang berada di samping mereka, yang pada gilirannya membuat gerakan-gerakan serupa dan menyentuh pula bagian-bagian kecil lainnya. Hal inilah yang dinamakan dengan laju pertumbuhan getaran.

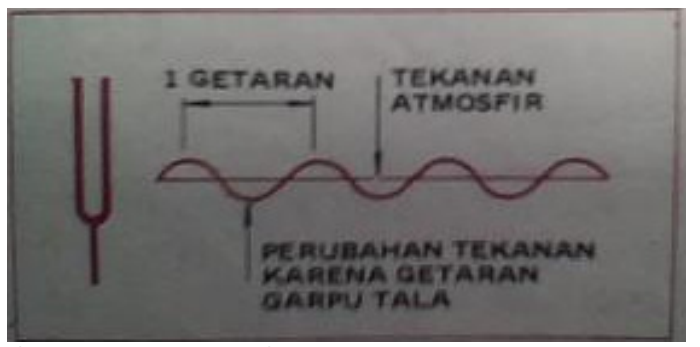

Gambar 4. Garpu tala yang dipukul menghasilkan perubahan tekanan udara karena getarannya dan menghasilkan bunyi, Farina (2000)

Rambatan gelombang bunyi disebabkan oleh lapisan perapatan dan peregangan partikel-partikel udara yang bergerak kea rah luar, yaitu karena penyimpangan tekanan. Hal ini sama saja dengan penyebaran gelombang air pada permukaan kolam dan titik dimana batu dijatuhkan pada kolam tersebut. Partikelpartikel udara yang meneruskan gelombang bunyi tidak berubah posisi normalnya; mereka hanya bergetar sekitar posisi kesetimbangannya, yaitu posisi partikel bila tidak ada gelombang bunyi yang diteruskan. Kecepatan rambat gelombang bunyi pada temperatur ruang $68^{\circ} \mathrm{F}\left(20^{\circ} \mathrm{C}\right)$ adalah sekitar $1.130 \mathrm{ft} / \mathrm{s}(344 \mathrm{~m} / \mathrm{s})$. Apabila suatu gelombang bunyi yang berupa energy mengalami penumbukkan pada suatu bahan atau material tertentu maka kemungkinan yang terjadi dari gelombang bunyi tersebut antara lain dipantulkan (deflect), diserap (absorp), disebarkan (difuse), dibelokkan (diffraction), dengung, ataupun diteruskan.

\section{Penyerapan suara (Sound Absorption)}

Bahan lembut, berpori dan kain serta berbagai bahan lainnya; termasuk manusia, menyerap sebagian besar gelombang bunyi yang menumbuk kepadanya, dengan kata lain mereka adalah bahan penyerap bunyi. Dari definisi, penyerapan bunyi adalah perubahan energi bunyi menjadi suatu bentuk lain, biasanya panas, ketika melewati suatu bahan atau ketika menumbuk suatu permukaan. Jumlah panas yang dihasilkan pada perubahan energi ini adalah sangat kecil, sedang kecepatan perambatan gelombang bunyi tidak dipengaruhi oleh penyerapan.

Efisiensi penyerapan bunyi suatu bahan pada suatu frekuensi tertentu yang dinyatakan dengan suatu Koefisien Penyerapan Bunyi (coefficient of sound absorption). Koefisien penyerapan bunyi suatu permukaan adalah bagian energi bunyi datang yang diserap, atau tidak dipantulkan oleh permukaan. Satuan ini dinyatakan dalam huruf Geek $\alpha$. Nilai $\alpha$ dapat berada antara 0 sampai dengan 1; misalnya pada $500 \mathrm{~Hz}$ bila material akustik menyerap 65\% dari energi bunyi datang dan memantulkan 35\% daripadanya, maka koefisien penyerapan bunyi bahan ini adalah 0,65. Koefisien penyerapan bunyi berubah dengan sudut datang gelombang bunyi pada bahan dan denga frekuensi. Nilai koefisien penyerapan bunyi pada suatu frekuensi tertentu, diratarata terhadap semua sudut datang pada suatu frekuensi tertentu (datang acak).

Penyerapan bunyi suatu permukaan (penyerapan permukaan) diukur dalam sabins, sebelumnya disebut satuan jendela terbuka (open-window units). Satu sabin menyatakan suatu permukaan seluas $1 \mathrm{ft}^{2}$ (atau $1 \mathrm{~m}^{2}$ ) yang mempunyai koefisien penyerapan $\alpha=1.0$. penyerapan permukaan diperoleh dengan mengalikan luas permukaan dalam $\mathrm{ft}^{2}$ (atau $\mathrm{m}^{2}$ ), dengan koefisien penyerapan bunyinya. Berdasarkan standar ISO 11654:1997 tentang rating koefisien absorbsi suara pada material untuk 
komponen bangunan, didapatkan suatu acuan kelas koefisien absorbsi suara seperti berikut.



Gambar 5. Standar kelas koefisien absorbsi suara pada material, http://www.sasint.co.uk/ acoustic-comfort.php

Adalah suatu kebiasaan standar untuk membuat daftar nilai koefisien penyerapan bunyi pada wakil frekuensi standar yang meliputi bagian yang paling penting dari jangkauan audio, yaitu 125, 250, 500, 1000, 2000, 4000 dan $8000 \mathrm{~Hz}$ atau 128, 256, 512, 1024, 2048, 4096 dan 8192 Hz.

\section{METODE PENELITIAN}

Komposit dibuat dengan menggunakan serat tapis kelapa dengan matriks resin Unsaturated-Polyester (UPRs) jenis Yucalac 157 QBTN, campuran $1 \%$ hardener jenis MEKPO (Methyl Ethyl Ketone Peroxide) dan perendaman serat dalam larutan alkali $\mathrm{KMnO}_{4}$. Metode produksi yang digunakan adalah metode pultrusion dengan orientasi serat acak. Variasi fraksi volume serat 20, 25 dan $30 \%$, dan apanjang seart 5,10 dan 15 $\mathrm{mm}$ dengan frekwensi inputan 250, 500, 1000, 2000 dan $4000 \mathrm{~Hz}$.

Alat uji uji koefisien/angka serapan suara bahan (impedance tube standing wave method) yang digunakan dengan spesifikasi :

$>$ Measuring Amplifier merk Brüel \& Kjær type 2636

> Sine Generator merk Brüel \& Kjær type 1054

Pelaksanaan pengujiannya dapat dijelaskan sebagai berikut: 1) Tempatkan bahan yang akan diuji pada ujung tabung yang telah ditentukan. 2) Posisikan 'ON' pada Sine Generator kemudian atur frekuensi masukan pada sine generator sesuai dengan frekuensi yang diteliti dengan cara memutar aturan decrease/increase pada sine generator, atau dengan meng-input masukkan frekuensi dengan menekan tombol 'Ent' lalu masukan nominal angka frekuensi yang diinginkan, tekan tombol 'Ent' lagi, ubah status gelombang dari 'off' ke 'cont' untuk mengaktifkan gelombang sinus.3) Cari lalu catat tekanan maksimum dan minimum di dalam standing wave tube, dengan cara menggeser-geserkan mikrofon secara perlahan. Besarnya tekanan maksimum maupun minimum dapat dibaca pada tampilan di dalam komputer atau laptop dengan menggunakan software Adobe Audition. 4) Pastikan ketepatan antara nilai lamda $(\lambda)$ teoritis/hitung mendekati nilai lamda pada hasil responsi tekanan maksimum dan minimum untuk menetapkan nilai kepastian dari tekanan maksimum dan minimum bahan berdasarkan pada tampilan yang tertera di laptop atau komputer. 5) Hitung nilai $n$ dengan persamaan

$n=\frac{P_{\text {maks }}}{P_{\min }}$

kemudian hitung nilai koefisien/angka serapan suara bahan dengan persamaan

$$
\alpha=1-\left(\frac{n-1}{n+1}\right)^{2}
$$

\section{HASIL DAN PEMBAHASAN}

Berikut adalah data hasil pengujian serapan suara untuk variasi panjang dan fraksi volume serat tapis kelapa.

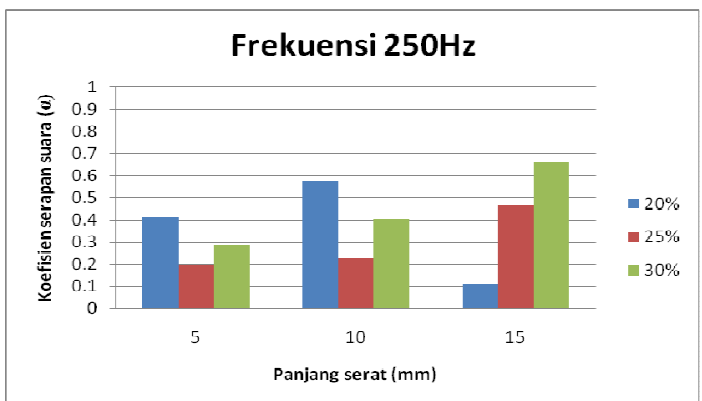

Gambar 6. Koefisien serapan suara rata-rata di tiap panjang serat dan variasi fraksi volume pada inputan frekuensi $250 \mathrm{~Hz}$

Dilihat dari hasil pengujian koefisien serapan suara ini, didapat hasil yang bervariasi seperti pada tabel 1. Pada dasarnya nilai yang didapat dari hasil pengujian tersebut bersifat identik. Dalam artian secara keseluruhan data hasil ujinya memiliki angka koefisien serapan suara yang lebih dari $0,1(\alpha>0,1)$. Hal ini disebabkan karena adanya perbedaan 
karakteristik dari permukaan komposit dan juga densitas dari material uji. Untuk hasil tertinggi terdapat pada inputan frekuensi 2000 $\mathrm{Hz}$ dengan komposisi panjang serat $5 \mathrm{~mm}$ dengan fraksi volume $20 \%$ yaitu sebesar 0.930. Mengacu pada standar ISO 11654 :1997 mengenai level rating koefisien absorpsi suara pada material untuk ruang, bahan ini diklasifikasikan sebagai "Sound Absorption Coeffitient Class A" dengan batas kelas adalah 0,90 - 1,00 (Seddeq, 2009).

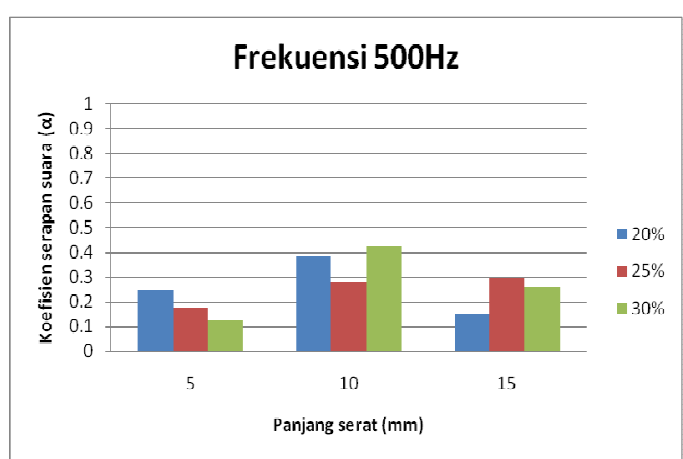

Gambar 7. Koefisien serapan suara rata-rata di tiap panjang serat dan variasi fraksi volume pada inputan frekuensi $500 \mathrm{~Hz}$

Tabel 1. Rata-rata koefisien serapan suara (a)

\begin{tabular}{|c|c|c|c|c|}
\hline \multirow{3}{*}{ Spesimen Uji } & \multirow{2}{*}{$\begin{array}{c}\text { Fraksi Volume } \\
\text { Serat (\%) }\end{array}$} & \multicolumn{3}{|c|}{$\begin{array}{c}\text { Koefisien Serapan Suara }(\alpha) \\
\text { Rata-Rata }\end{array}$} \\
\cline { 2 - 5 } & & \multicolumn{3}{|c|}{ Frekuensi Input $(\mathrm{Hz})$} \\
\cline { 2 - 5 } & 20 & 250 & 500 & 1000 \\
\hline \multirow{3}{*}{$\begin{array}{c}\text { Panjang serat } \\
5 \mathrm{~mm}\end{array}$} & 25 & 0.274 & 0.166 & 0.498 \\
\cline { 2 - 5 } & 30 & 0.287 & 0.176 & 0.599 \\
\cline { 2 - 5 } & 20 & 0.575 & 0.382 & 0.551 \\
\hline \multirow{3}{*}{$\begin{array}{c}\text { Panjang serat } \\
10 \mathrm{~mm}\end{array}$} & 25 & 0.227 & 0.281 & 0.715 \\
\cline { 2 - 5 } & 30 & 0.402 & 0.425 & 0.753 \\
\hline \multirow{3}{*}{$\begin{array}{c}\text { Panjang serat } \\
15 \mathrm{~mm}\end{array}$} & 20 & 0.114 & 0.147 & 0.580 \\
\cline { 2 - 5 } & 25 & 0.467 & 0.295 & 0.865 \\
\cline { 2 - 5 } & 30 & 0.661 & 0.260 & 0.785 \\
\hline
\end{tabular}

\begin{tabular}{|c|c|c|c|}
\hline \multirow{3}{*}{ Spesimen Uji } & \multirow{2}{*}{$\begin{array}{c}\text { Fraksi Volume Serat } \\
(\%)\end{array}$} & \multicolumn{2}{|c|}{$\begin{array}{c}\text { Koefisien Serapan Suara }(\alpha) \\
\text { Rata-Rata }\end{array}$} \\
\cline { 3 - 4 } & & \multicolumn{2}{|c|}{ Frekuensi Input $(\mathrm{Hz})$} \\
\cline { 2 - 4 } & & 2000 & 4000 \\
\hline \multirow{3}{*}{$\begin{array}{c}\text { Panjang serat } \\
5 \mathrm{~mm}\end{array}$} & 20 & 0.930 & 0.760 \\
\cline { 2 - 4 } & 25 & 0.332 & 0.605 \\
\hline \multirow{3}{*}{$\begin{array}{c}\text { Panjang serat } \\
10 \mathrm{~mm}\end{array}$} & 30 & 0.813 & 0.507 \\
\cline { 2 - 4 } & 20 & 0.707 & 0.820 \\
\cline { 2 - 4 } & 25 & 0.870 & 0.664 \\
\hline \multirow{3}{*}{$\begin{array}{c}\text { Panjang serat } \\
15 \mathrm{~mm}\end{array}$} & 30 & 0.825 & 0.796 \\
\cline { 2 - 4 } & 20 & 0.859 & 0.776 \\
\cline { 2 - 4 } & 25 & 0.922 & 0.546 \\
\hline
\end{tabular}






Gambar 8. Koefisien serapan suara rata-rata di tiap panjang serat dan variasi fraksi volume pada inputan frekuensi $1000 \mathrm{~Hz}$

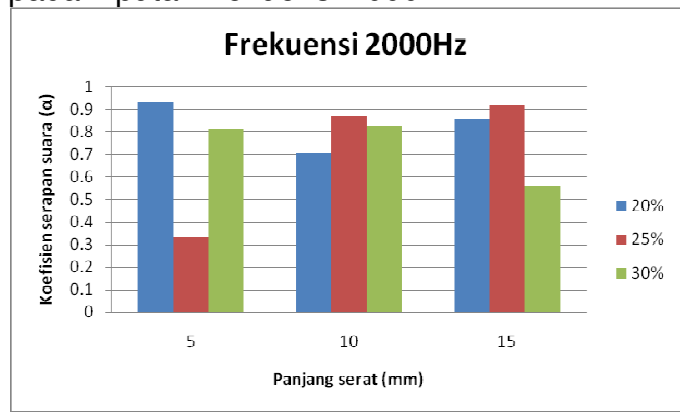

Gambar 9. Koefisien serapan suara rata-rata di tiap panjang serat dan variasi fraksi volume pada inputan frekuensi $2000 \mathrm{~Hz}$

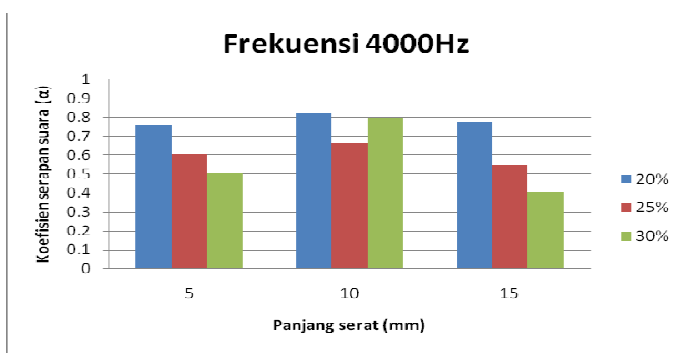

Gambar 10. Koefisien serapan suara rata-rata di tiap panjang serat dan variasi fraksi volume pada inputan frekuensi $4000 \mathrm{~Hz}$

\section{SIMPULAN}

Dari pengolahan data hasil pengukuran koefisien absorpsi suara dapat ditarik beberapa kesimpulan sebagai berikut:

1. Komposit berpenguat serat tapis kelapa dapat digunakan sebagai bahan peredam suara walaupun tidak terdapat kecenderungan tertentu antara variasi panjang dan fraksi volume serat terhadap nilai koefisien serapan suara.

2. Nilai tertinggi koefisien serapan suara terdapat pada inputan frekuensi $2000 \mathrm{~Hz}$ yaitu pada komposisi komposit dengan panjang serat $5 \mathrm{~mm}$ dan fraksi volume serat $20 \%$ yaitu 0,930 . Mengacu pada standar ISO 11654 :1997 mengenai level rating koefisien absorpsi suara pada material untuk ruang, yang biasa diklasifikasikan sebagai "Sound Absorption Coeffitient Class A" dengan batas kelas adalah $0,90-1,00$.

\section{UCAPAN TERIMAKASIH}

Tim Peneliti mengucapkan terima kasih kepada DP2M DIKTI yang telah mendanai penelitian ini melalui skim Penelitian Fundamental tahun 2015 dengan Surat Perjanjian Penugasan Dalam Rangka Pelaksanaan Penelitian Kompetitif Nasional Tahun Anggaran 2015, Nomor: 311142/UN14.2/PNL.01.03.00/2015, tanggal 30 Maret 2015. Ungkapan terima kasih yang tulus juga kami sampaikan kepada Ary Dharma Susila yang telah membantu kegiatan penelitian ini.

\section{DAFTAR PUSTAKA}

Anonimous, Percobaan pengukuran koefisien redaman akustik bahan, Universitas Gajah Mada, Yogyakarta.

Brahmakumar, M., Pavithran, C., Pillai, R.M., 2005, Coconut fiber reinforced polyethylene composites such as effect of natural waxy surface layer of the fiber on fiber or matrix interfacial bonding and strength of composites, Elsevier, Composite Science and Technology, 65 pp. 563-569.

Farina, Angelo, Fausti, Patrizio., 2000, Standing wave tube techniques for measuring the normal incidence absorption coefficient: Comparison of different experimental setups. Universitá di Parma, Italy.

Gibson, R. F., 1994, Principles Of Composite Material Mechanics, McGraw Hill Book Co.

http://www.sasint.co.uk/acoustic-comfort.php.

Jacobs, James, A., Thomas F., 2005, Engineering materials technology, Structures, Processing, Properties and Selection $5^{\text {th }}$, New Jersey Columbus, Ohio.

Koizumi, T., 2000, The development of sound absorpsing material using natural bamboo fiber, Jurnal Universitas Doshisha, Jepang.

Seddeq, Hoda S., 2009, Factors influencing acoustic performance of sound absorptive materials, Australian Journal of Basic and Applied Sciences, 3(4): 4610-4617 ISSN 1991-8178, INSInet Publication.

Youneung-Lee., 2003, The development of sound absorpsing material using 
Dinamika Teknik Mesin, Volume 6 No. 1 Juni 2016

p. ISSN: 2088-088X, e. ISSN: 2502-1729

Astika, Dwijana: Karakteristik serapan suara komposit polyester penguat serat tapis kelapa.

natural bamboo fiber, Jurnal

Universitas Doshisha, Jepang. 